\title{
Paleobotany of Livingston Island: The first report of a Cretaceous fossil flora from Hannah Point
}

\author{
M. Leppe, ${ }^{1}$ W. Michea, ${ }^{2}$ C. Muñoz, ${ }^{3}$ S. Palma-Heldt, ${ }^{3}$ and F. Fernandoy ${ }^{3}$ \\ ${ }^{1}$ Scientific Department, Chilean Antarctic Institute-INACH, Plaza Muñoz Gamero 1055, Punta Arenas, Chile (mleppe@inach.cl) \\ ${ }^{2}$ Departamento de Geología, Universidad de Chile, Plaza Ercilla 803, Casilla 13518, Correo 21, Santiago, Chile (ondodelaonda@yahoo.es) \\ ${ }^{3}$ Departamento Ciencias de La Tierra, Universidad de Concepción, Casilla 160-C, Concepción, Chile (carlomunoz@udec.cl).
}

\begin{abstract}
This is the first report of a fossil flora from Hannah Point, Livingston Island, South Shetland Islands, Antarctica. The fossiliferous content of an outcrop, located between two igneous rock units of Cretaceous age are mainly composed of leaf imprints and some fossil trunks. The leaf assemblage consists of 18 taxa of Pteridophyta, Pinophyta and one angiosperm. The plant assemblage can be compared to other Early Cretaceous floras from the South Shetland Islands, but several taxa have an evidently Late Cretaceous affinity. A Coniacian-Santonian age is the most probable age for the outcrops, supported by previous $\mathrm{K} / \mathrm{Ar}$ isotopic studies of the basalts over and underlying the fossiliferous sequence.
\end{abstract}

Citation: Leppe, M., W. Michea, C. Muñoz, S. Palma-Heldt, and F. Fernandoy (2007), Paleobotany of Livingston Island: The first report of a Cretaceous fossil flora from Hannah Point, in Antarctica: A Keystone in a Changing World - Online Proceedings of the $10^{\text {th }}$ ISAES, edited by A. K. Cooper and C. R. Raymond et al., USGS Open-File Report 2007-1047, Short Research Paper 081, 4 p.; doi:10.3133/of2007-1047.srp081

\section{Introduction}

The Cretaceous was a crucial time of vegetation change, due largely to the evolutionary and geographic radiation of angiosperms. Throughout the Late Cretaceous angiosperms progressively infiltrated the pre-existing vegetation, but gymnosperms, ferns and sphenophytes dominated land-plant biomass until the Cenozoic (Spicer et al., 1993; Cantrill and Poole, 2002).

In the Turonian-Coniacian of the Antarctic, the abundance and diversity of angiosperms remained low (Dettmann, 1989), while cryptogams were still an important part of the vegetation. This was, however, an important transitional time when the established southern podocarp conifer forest vegetation was diversifying, and new angiosperm families that henceforth typified southern vegetation started to appear (Askin, 1989; Crame, 1992, Cantrill and Poole 2002, 2004). Palynomorph assemblages indicate the predominance of temperate, podocarp-araucarian-fern forest vegetation, with lycopod and fern moorland vegetation in some areas (Douglas and Williams, 1982; Dettmann, 1986; Dettmann and Thomson, 1987; Truswell, 1990; Dettman et al., 1992; Cantrill and Poole, 2005). The podocarp-araucarian-fern forest association continued through this interval in southern high latitudes (Askin and Spicer, 1995). The southern high latitude region was a locus of evolutionary innovation from the Turonian to the end of the Cretaceous (Askin and Spicer, 1995). This important forest dominated southern high latitude forests from the Santonian through the Paleocene, and produced pollen. It is now restricted to wet, cool temperate, maritime western margins of Tasmania (Dettmann, 1989).

A rich Campanian leaf assemblage from King George Island, South Shetland Islands, suggests a broad-leaved forest community, including evergreen types (with thick, coriaceous leaves) and deciduous Nothofagus growing in a subhumid mesothermal climate (Birkenmajer and Zastawniak, 1989). Abundant ferns, especially gleicheniaceous types, grew on moist lowland areas at the end of the Cretaceous.

The fossiliferous leaf content of Hannah Point (Figure 1) exhibits the dominance of a podocarp-araucarian-fern forest association, but with evidence of angiosperms, restricted to the Late Cretaceous in the South Shetland Islands.

\section{Geological setting}

Lithologies that belong to the main tectonic units of the Antarctic Peninsula region (such as forearc basin, magmatic arc and extension-related volcanics) crop out on Livingston Island (Pallàs et al., 1999; Hathway, 2000). Smellie et al. (1996) ruled out any cogenetic relationship between the volcanic rocks of Hannah Point and the volcanics included in the Byers Formation, but suggested a possible cogenetic relationship with the dolerites cropping out at Siddons Point. Later isotopic analyses $(\mathrm{Sr}, \mathrm{Nd}$ and $\mathrm{Pb}$ ) and the study of $\mathrm{La} / \mathrm{Sm}-\mathrm{La}$ and $\mathrm{Ce} / \mathrm{Yb}-\mathrm{Ce}$ pairs indicate that the rocks of Hannah Point display crustal contamination and correspond to a different magma source from the rocks of Siddons Point, Byers Peninsula and Cape Shirreff (Xiangshen et al., 1996).

Hannah Point consists of a homoclinal, northnorthwest-dipping sequence with a thickness of about 500 $\mathrm{m}$, comprising basaltic-andesite to dacite lavas interbedded with a variety of pyroclastic and thin sedimentary beds. Two lava samples were obtained: both are basaltic andesites, obtained from the top and just above the centre of the sequence (Smellie et al., 1996). According to Hobbs (1968), the basal $43 \mathrm{~m}$ of the Hannah Point succession consists of massive andesites interbedded with green agglomerates and amygdaloidal lava sand tuffs. The overlying $110 \mathrm{~m}$ are composed of friable agglomerates, fissile ashes and amygdaloidal lavas, while the top $195 \mathrm{~m}$ are composed of massive andesite layers (much thicker than the basal ones) interbedded with amygdaloidal lavas. 


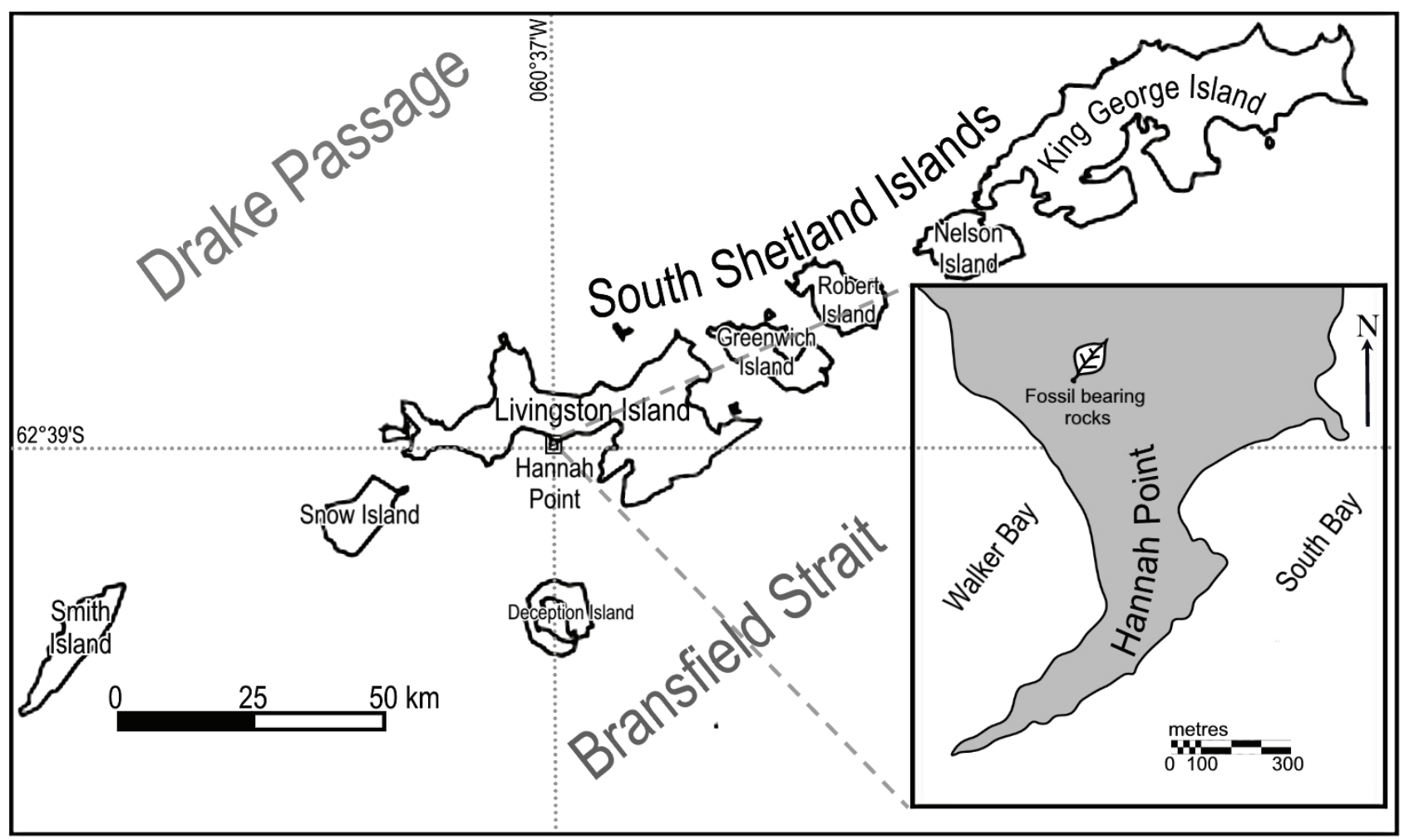

Figure 1. Locality map showing the South Shetland Islands and a detail of Hannah Point.

Pallàs et al. (1999) defined five units for the volcanic succession cropping out at Hannah Point. The upper part corresponds to an approximately $80 \mathrm{~m}$ thick coherent andesitic lava layer that shows columnar jointing. Smellie et al. (1996) analyzed, with K-Ar isotopic method, two igneous rock samples from Hannah Point that yielded conflicting ages of $87.9 \pm 2.6 \mathrm{My}$ and $67.5 \pm 2.5 \mathrm{My}$ from the centre and top of the sequence, respectively. The younger sample belongs to a $150 \mathrm{~m}$ thick upper part of the E unit of Pallàs et al. (1999). However, in 1999, when the paper of Pallàs et al. was published, the ice and snow covered the lower part of the unit E. During the 20062007 field season of the XLIII Chilean Antarctic Scientific Expedition, the exposure of the lower layers of the Pallàs E unit was revisited, and a sequence was discovered consisting of $25 \mathrm{~m}$ thick fine-grained green sandstone with abundant leaf imprints.

\section{Paleobotany}

The leaf megaflora of the Hannah Point outcrops consists of: Adiantites sp., Elatocladus sp., Matonia jeffersonii, Angiosperm form 1 and 2, Gleichenites sanmartinii, Podozamites cf. binatus, Brachyphyllum sp., Microphyllopteris unisoria, Ptilophyllum sp., Thyrsopteris elegans, Coniopteris sp., Sphenopteris sp., Cladophlebis antarctica, Pachypteris sp., Cladophlebis oblonga (Figure 2).

\section{Discussion}

Several leaf types have been described from the Albian-Aptian floras of Byers Peninsula and Snow Island, and less from Alexander Island and James Ross Island, reflecting a strong connection with the lower Cretaceous Antarctic floras, but the presence of other common elements to younger outcrops, puts a reasonable doubt on an Early Cretaceous age for this flora.

The fossil-bearing rocks belong to a previously dated volcanic-sedimentary succession at Hannah Point. According to this previous isotopic analysis (Smellie et al., 1996; Pallàs et al., 1999) the age could be Coniacian and probably also Santonian age, but it is necessary to confirm that with other geochemical analyses. The sequences vary in composition locally, reflecting lateral facies changes, taphonomic processes and climatic differences. The assemblages are commonly dominated by ferns, mainly of the families Osmundaceae, Dicksoniaceae and Gleicheniaceae, and foliage of conifers (mostly referable to the Podocarpaceae). The occurrence of angiosperm leaves is rare, but recently angiosperm pollen has been found in pollen and spore-bearing rocks from Hannah Point (Palma-Heldt, personal communication). The age proposed here is similar to the isotopic dating (Pallàs et al., 1999; Smellie et al., 1996) and with the phases described by Cantrill and Poole (2005) for the vegetational development in Antarctica during the Cenomanian to Santonian. 

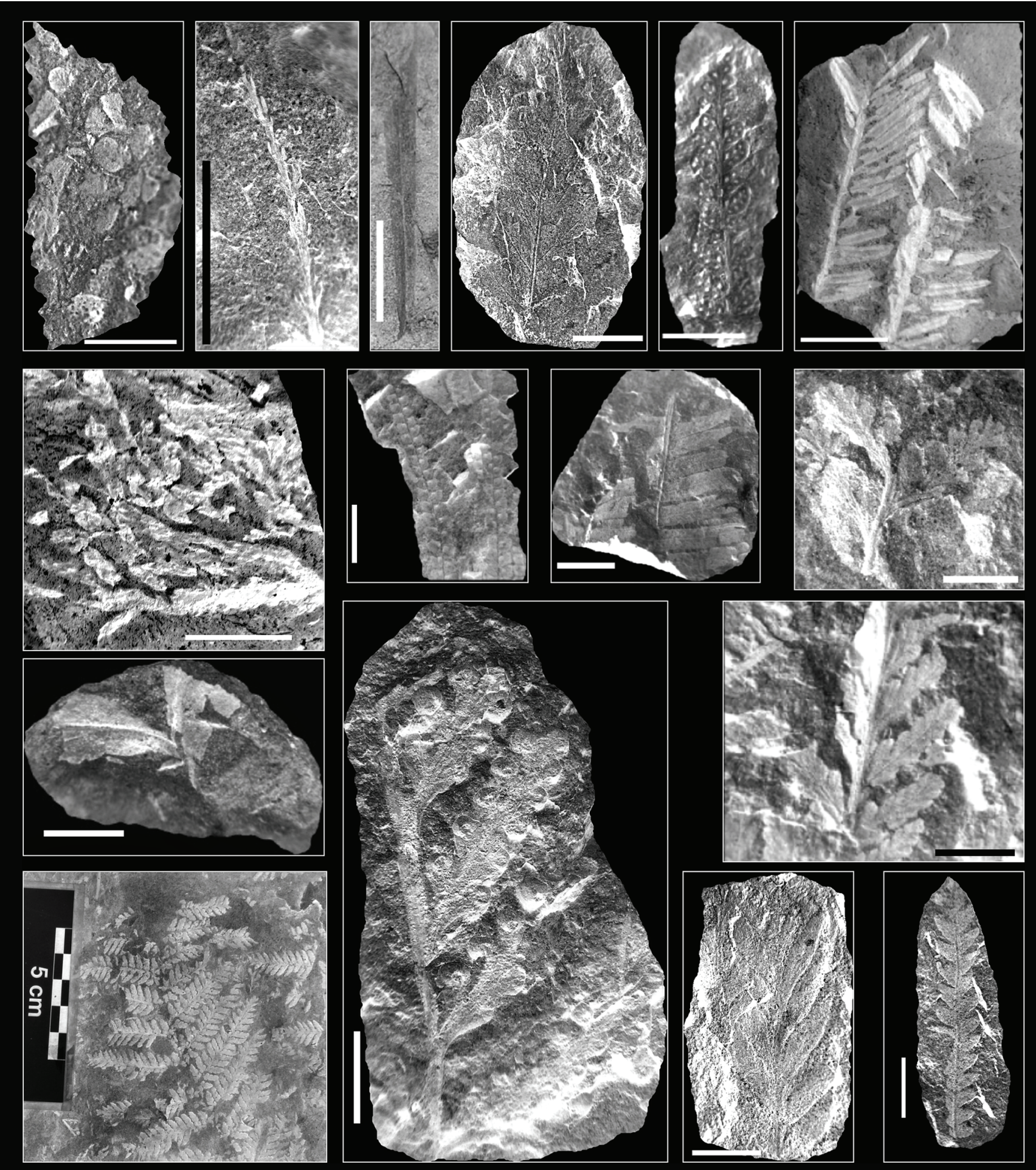

Figure 2. A. Adiantites sp .; B. Elatocladus sp.; C. Matonia jeffersonii ; D. Angiosperm form 1 ; E. Gleichenites sanmartinii ; F. Podozamites cf. binatus ; G. Brachyphyllum sp.; H. Microphyllopteris unisoria ; I. Ptilophyllum sp.; J. Thyrsopteris elegans ; K. Angiosperm form 2 ; L. Coniopteris sp.; M. Sphenopteris sp.; N. Cladophlebis antarctica; O. Pachypteris sp.; P. Cladophlebis oblonga. Scale bars $=1 \mathrm{~cm}$. 
It is not easy to understand how angiosperms migrated rapidly into the conifer-fern dominated floras of phase one and how they subsequently rose to dominance within phase two due to the lack of knowledge of Cenomanian to Turonian floras (Cantrill and Poole, 2005). By phase 3 of the Antarctic ecosystem evolution fossil leaf floras suggest that angiosperms were diverse (Hayes, 1999) and an array of angiosperms had evolved to form a significant tree-forming element of the vegetation during the Coniacian (Chapman and Smellie, 1992; Poole and Cantrill, 2001). Hannah Point's flora can help to complete the lack of knowledge of the evolution of the plant communities of the early upper Cretaceous.

Acknowledgements. This paper was prepared as a collaborative work between the Chilean Antarctic Institute (INACH) project 05-06 and the Chilean Bicentennial Ring of Science and Technology Program (PBCT) "Geological Connection between West Antarctica and Patagonia since the Late Paleozoic", both under the IPY Full Proposal GeoPaSAA (N 115), project under the Plates \& Gates IPY Cluster Project. Thanks to photographer and graphic designer Jeniffer Muñoz.

\section{References}

Askin, R. A. (1989), Endemism and heterochroneity in the Late Cretaceous (Campanian) to Paleocene palynofloras of Seymour Island, Antarctica: implications for origins, dispersal and palaeoclimates of southern floras, in Origins and Evolution of the Antarctic Biota, edited by J. A. Crame, pp. 107-119, Geol. Soc. Lond. Spec. Publ., 47.

Askin, R. A., and R. A. Spicer (1995), The Late Cretaceous and Cenozoic History of Vegetation and Climate at Northern and Southern High Latitudes: a comparison, in Effects of Past Global Change on Life, Panel on Effects of Past Global Change on Life, edited by the Board on Earth Sciences and Resources, Commission on Geosciences, Environment, and Resources, National Research Council, pp. 156173, National Academy Press, Washington, D.C., USA.

Birkenmajer, K., and E. Zastawniak (1989), Late Cretaceous-Early Tertiary Floras of King George Island, West Antarctica: their stratigraphic distribution and palaeoclimatic significance, in Origins and Evolution of the Antarctic Biota, edited by J. A. Crame, pp. $227-$ 240, Geol. Soc. Lond. Spec. Publ., 47.

Cantrill, D. J., and I. P. Poole (2002), Cretaceous patterns of floristic change in the Antarctic Peninsula, in Palaeobiogeography and Biodiversity Change: a comparison of the Ordovician and MesozoicCenozoic radiations, edited by A. Owens, and J. A. Crame, pp. 141152, Geol. Soc. Lond. Spec. Publ., 194.

Cantrill, D. J., and I. P. Poole (2005), Taxonomic turnover and abundance in Cretaceous to Tertiary wood floras of Antarctica: implications for changes in forest ecology, Palaeogeogr. Palaeoclimatol. Palaeoecol., 215, 205-219.
Chapman, J. L., and J. L. Smellie (1992), Cretaceous fossil wood and palynomorphs from Williams Point, Livingston Island, Antarctic Peninsula, Rev. Palaeobot. Palynol., 74, 163-192.

Crame, J. A. (1992), Late Cretaceous palaeoenvironments and biotas: an Antarctic perspective, Ant. Sci., 4, 371-382.

Dettman, M. E., R. E. Molnar, J. G. Douglas, D. Burger, C. Fielding, H. T. Clifford, J. E. Francis, P. Jell, T. Rich, W. Wade, P. V. Rich, N. Pledge, A. Kemp, and A. Rozefelds (1992), Australian Cretaceous terrestrial faunas and floras: biostratigraphic and biogeographic implications, Cret. Res., 13, 207-262.

Dettmann, M. E. (1989), Antarctica: Cretaceous cradle of austral temperate rainforests?, in Origins and Evolution of the Antarctic Biota, edited by J. A. Crame, pp. 89-105, Geol. Soc. Lond. Spec. Publ., 47.

Dettmann, M. E. (1986), Significance of the Cretaceous-Tertiary spore genus Cyatheacidites in tracing the origin and migration of Lophosoria (Filicopsida), Spec. Pap. Paleontol., 35, 63-94.

Dettmann, M. E., and M. R. A. Thomson (1987), Cretaceous palynomorphs from the James Ross Island area, Antarctica - a pilot study, Bull. B.A.S, 77, 13-59.

Douglas, J. G., and G. E. Williams (1982), Southern polar forests: The Early Cretaceous floras of Victoria and their palaeoclimatic significance, Palaeogeogr. Palaeoclimatol. Palaeoecol., 39, 171-185.

Hathway, B. (2000), Continental rift to back-arc basin: JurassicCretaceous stratigraphical and structural evolution of the Larsen Basin, Antarctic Peninsula, J. Geol. Soc. Lond., 157, 417-432.

Hayes, P. A. (1999), Cretaceous angiosperm floras from Antarctica. Unpublished Ph.D. thesis, University of Leeds, Leeds, UK.

Hobbs, G. J. (1968), The geology of the South Shetland Islands. IV. The Geology of Livingston Island. B.A.S. Sci. Rep., 47.

Pallàs, R., C. Soriano, X. Zheng,, F. Sàbat, and J. M. Casas (1999), Volcanic Stratigraphy of Hannah Point, Livingston Island, South Shetland Islands, Antarctica, Acta Geologica Hispanica, 34(4), 323328.

Poole, I. P., and D. J. Cantrill (2001), Fossil woods from Williams Point Beds, Livingston Island, Antarctica: a Late Cretaceous southern high latitude flora, Palaeontology, 44, 1081-1112.

Smellie, J. L., R. Pallàs, F. Sàbat, and Z. Xiangsheng (1996), Age and correlation of volcanism in central Livingston Island, South Shetland Islands: K-Ar and geochemical constraints, J. S. Am. Earth Sci., 9(3/4), 265-272.

Spicer, R. A., P. M. Rees, and J. L. Chapman (1993), Cretaceous phytogeography and climate signals, Phil. Trans. Roy. Soc. Lond., Ser. B, 341, 277-286.

Truswell, E. M. (1990), Cretaceous and Tertiary vegetation of Antarctica: a palynological perspective, in Antarctic Palaeobiology: its role in the reconstruction of Gondwana, edited by T. N. Taylor, and E. L. Taylor, pp. 71-88, Springer Verlag, Berlin.

Xiangshen, Z., F. Sàbat, and J. L. Smellie (1996), Mesozoic-Cenozoic Volcanism on Livingston Island, South Shetland Islands, Antarctica: Geochemical Evidences for Multiple Magma Generation Processes, Korean J. Polar Res., 7(1/2), 35-45. 